\title{
PENERAPAN METODE ROLE PLAYING UNTUK MENINGKATKAN MOTIVASI DAN HASIL BELAJAR PKN SISWA TENTANG MUSYAWARAH KELAS II DI SD
}

\section{MASNUR}

Email: masnur1985@gmail.com

\section{STKIP Muhammadiyah Enrekang}

\begin{tabular}{ll}
\hline Keyword & Abstract \\
\hline PKn, metode & Permasalahan utama dalam penelitian ini adalah apakah penerapan metode role \\
role playing, & playing untuk meningkatkan motivasi dan hasil belajar PKn siswa tentang \\
motivasi & mehyawarah kelas II di SD. Pembelajaran cenderung berorientasi pada guru, \\
belajar, hasil & siswa. Hal ini mengakibatkan kurangnya motivasi belajar pada siswa dalam \\
belajar. & mengikuti proses pembelajaran di kelas. Hasil belajar siswa juga belum memenuhi \\
& kriteria ketuntasan minimal yang ditentukan. Kondisi tersebut membutuhkan suatu \\
& pembelajaran yang dapat menyelaraskan ranah kognitif, afektif dan psikomotor yaitu \\
& dengan menerapkan metode pembelajaran role playing pada mata pelajaran PKn. \\
& Metode role playing diterapkan karena dapat membangun semangat dan antusiasme \\
& siswa dalam pembelajaran. Penelitian ini menggunakan metode penelitian tindakan \\
& kelas. Subjek penelitian dalam penelitian ini adalah seluruh siswa kelas II SDN 1 \\
& Enrekang. Pengumpulan data menggunakan metode observasi, angket dan tes hasil \\
& belajar siswa. Instrumen penelitian yang digunakan adalah lembar observasi guru \\
& dan siswa, motivasi belajar dan hasil belajar siswa. Hasil penelitian ini menunjukkan \\
& suatu peningkatan pada setiap aspek tujuan penelitian yang dilakukan. Berdasarkan \\
& hasil penelitian dapat disimpulkan bahwa penerapan metode role playing pada \\
& pembelajaran PKn dapat meningkatkan motivasi dan hasil belajar siswa kelas II SDN \\
& 1 Enrekang.
\end{tabular}

\section{PENDAHULUAN}

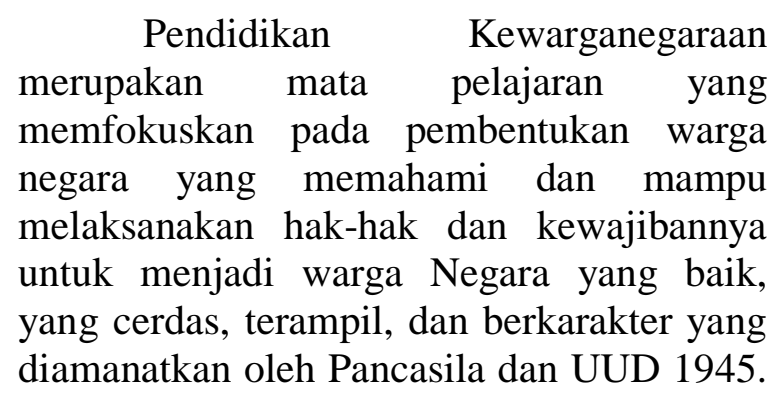

Pendidikan Kewarganegaraan (Citizenship Education) merupakan mata pelajaran juga memfokuskan pada pembentukan diri yang beragam dari segi agama, sosio-kultural, bahasa, usia, dan suku bangsa.

Pendidikan

Kewarganegaraan merupakan salah satu bidang studi yang menduduki peranan penting dalam pendidikan. Sebagai bukti adalah pelajaran Pendidikan Kewarganegaraan diberikan 
kepada semua jenjang pendidikan mulai dari Sekolah Dasar sampai Perguruan Tinggi. Mengingat pentingnya Pendidikan Kewarganegaraan, maka dalam pengajarannya bukan hanya untuk mengetahui dan memahami apa yang terkandung dalam Pendidikan Kewarganegaraan itu sendiri, tetapi lebih menekankan pada pola berfikir siswa agar dapat memecahkan masalah secara kritis, logis, kreatif, cermat, dan teliti.

Konsep pendidikan kewarganegaraan sebagai citizenchip education, yang seharusnya mengarah pada pembentukan karakter (character building) terabaikan. Dalam pembelajaran guru cenderung memihak pada tuntutan formal kurikuler dan kurang memperhatikan pengembangan pendidikan kewarganegaraan. Pembelajaran sosial nilai-nilai Pancasila cenderung berubah peran dan fungsinya menjadi proses indoktrinasi ideologi. Paradigma pendidikan kewarganegaraan yang kini ada kelihatan masih belum sinergistik. Kerangka acuan teoritik yang menjadi titik tolak untuk merancang dan melaksanakan pendidikan kewarganegaraan dalam masing-masing statusnya belum saling mendukung secara komprehensif.

Berdasarkan observasi pembelajaran di SDN 1 Enrekang belum berhasil sepenuhnya. Anak cenderung tidak begitu tertarik dengan pelajaran PKn karena selama ini pelajaran PKn dianggap sebagai pelajaran yang hanya mementingkan hafalan semata, kurang menekankan aspek penalaran sehingga menyebabkan rendahnya motivasi belajar PKn siswa di kelas. Kondisi ini tampak memunculkan kelemahan bagi siswa, jika dilihat dari tuntutan peran siswa dalam peningkatan mutu pendidikan, antara lain mereka kurang terlatih dalam menemukan/mencari, menganalisis dan menggunakan informasi sebagai akibat dari sajian materi yang bersifat kognitif tanpa banyak memuat masalah secara fakta.
Pembelajaran seperti itu masih didominasi oleh aktifitas gurunya, sehingga selama proses pembelajaran berlangsung tidak terlihat adanya motivasi belaar siswa didalam kelas. Hal ini berimplikasi terhapat tdari nilai rata-rata kelas yang diperoleh oleh siswa berkisar 68,3 masih dibawah KKM sebesar 75 .

Guna mengatasi permasalahan tersebut, diperlukan adanya metode pembelajaran yang mengedepankan proses belajar dan mengutamakan aktifitas menyenangkan siswa di dalam kelas. Salah satu metode tersebut adalah role playing atau metode bermain peran. Menurut Hamdani (2011: 87) metode role playing adalah cara penguasaan bahan-bahan pelajaran melalui pengembangan imajinasi dan penghayatan siswa. Pengembangan imajinasi dan penghayatan siswa dilakukan dengan memerankannya sebagai tokoh hidup atau benda mati. Melalui role playing, siswa dapat meningkatkan kemampuan mereka untuk mengenali perasaan mereka sendiri dan orang lain. Mereka dapat memperoleh perilaku baru untuk menangani situasi sulit sebelumnya dan mereka dapat meningkatkan kemampuan memecahkan masalah mereka.

Penerapan metode role playing dalam pembelajaran PKn dalam materi "Musyawarah", siswa akan dilatih sejak dini untuk mengenal dan memahami kegiatan musyawarah-musyawarah yang berlangsung dalam kehidupan sehari-hari. Melalui metode role playing guru dapat menciptakan pembelajaran yang menarik dan siswa dapat mengikuti kegiatan belajar mengajar dalam suasana yang menyenangkan. Berdasarkan uraian tersebut, rumusan masalah penelitian ini adalah dengan menerapan metode Role Playing dapat meningkatkan Motivasi dan Hasil Belajar PKn Siswa tentang musyawarah Kelas II di SDN 1 Enrekang. 


\section{KAJIAN TEORI}

Pendidikan Kewarganegaraan (civic education) dapat diartikan sebagai wahana untuk mengembangkan dan melestarikan nilai luhur dan moral yang berakar pada budaya bangsa Indonesia yang diharapkan dapat diwujudkan dalam bentuk perilaku kehidupan sehari-hari peserta didik sebagai individu, anggota masyarakat dalam kehidupan berbangsa dan bernegara. Menurut Cogan (1994: 4) civic education sebagai "...the foundational course work in school designed to prepare young citizens for anactive role in their communities in their adult lives". Maksudnya adalah suatu mata pelajaran dasar di sekolah yang dirancang untuk mempersiapkan warga negara muda agar kelak setelah dewasa dapat berperan aktif dalam masyarakat. Sehingga kelak diharapkan dapat dipersiapkan menjadi warga negara yang yang baik (good citizenship).

Mata pelajaran PKn merupakan mata pelajaran yang bersifat interdisipliner terutama disiplin ilmu hukum, politik dan filsafat moral. Sifat interdisipliner ini menjadikan PKn jelas batang keilmuannya (body of knowledge). Adapun ruang lingkup mata pelajaran Pendidikan Kewarganegaraan meliputi aspek-aspek diantaranya: 1) Persatuan dan kesatuan bangsa, 2) Norma, hukum dan peraturan, 3) Hak asasi manusia, 4) Kebutuhan warga negara, 5) Konstitusi negara, 6) Kekuasaan dan politik, 7) Pancasila dan 8) Globalisasi. Berdasarkan paparan tersebut, maka penelitian ini di fokuskan pada materi musyawarah (Depdikbud, 2006).

Istilah musyawarah telah dikenal bangsa Indonesia sejak zaman Kerajaan majapahit. Musyawarah merupakan salah satu asas/dasar Negara Indoensia yang membedakannya dari Negara-negara lain. Musyawarah tercantum di dalam sila keempat dari Pancasila. Musyawarah untuk mufakat pada dasarnya merupakan kesapahaman atau kata sepakat anatara pihak-pihak yang berbeda pendapat sehingga pemungutan suara dapat dihindarkan dan diharapkan semua pihak yang berbeda pendapat dapat menemukan keputusan tunggal.

Dalam musyawarah kita harus mementingkan kepentingan umum dari pada kepentingan pribadi. Setiap peserta musyawarah memiliki hak yang sama untuk mengeluarkan pendapat. Jika dalam musyawarah tidak mencapai kesepakatan, maka diadakan pengambilan suara terbanyak atau disebut voting. Hasil keputusan musyawarah harus dilaksanakan dengan penuh ikhlas dan tanggung jawab. Adapun sikap-sikap yang harus diterapkan dalam bermusyawarah agar musyawarah berjalan dengan baik yaitu 1) Menghargai pendapat orang lain; 2) Tidak memaksakan kehendak pada orang lain; 3) Mentaati peraturan musyawarah; 4) Mau menghargai suara terbanyak; 5) Mampu mengendalikan diri; 6) Menerima dan melaksanakan hasil/keputusan musyawarah. Namun ada hal-hal yang tidak boleh dilakukan dalam bermusyawarah adalah 1) Marah saat bermusyawarah, 2) Tidak menghormati pemimpin rapat, 3) Berbicara sendiri saat bermusyawarah, dan 4) Tidak menanggapi usul teman.

Proses pembelajaran PKn pada materi musyawarah harus di rencanakan sedemikian rupa sehingga tersistematisasi dan sesuai dengan prinsip-prinsip kegiatan belajar mengajar yaitu berpusat pada siswa (student centered), belajar disertai praktik (learning by doing) menuju proses pembelajaran yang menyenangkan, mengembangkan kompetensi sosial (learning to live together), imajinasi, mengembangkan kreativitas dan keterampilan memecahkan masalah (scientific problem solving), sehingga mampu meningkatkan motivasi belajar siswa. 
Menurut Woolfolk (2004: 350) motivasi adalah "as an internal state that arouses direct, and maintains behavior". Motivasi sebagai kekuatan dalam diri yang membangkitkan, mengarahkan, dan mempertahankan perilaku. Motivasi tidak dapat diamati secara secara langsung tetapi dapat dlihat dari tingkah laku seseorang, berupa rangsangan, dorongan atau pembangkit tenaga yang mengakibatkan munculnya tingka laku. Schunk, et al (2010: 5) mengemukakan bahwa motivasi memiliki hubungan dengan kemampuan belajar. Motivasi membawa suatu hubungan timbal balik antara proses belajar dan kemampuan belajar. Artinya, motivasi mempengaruhi proses belajar dan proses pembelajaran juga mempengaruhi motivasi siswa.

Proses pembelajaran bergantung pada kemampuan guru dalam memberikan motivasi kepada siswa, dalam hal ini guru dapat memberikan motivasi beajar dengan variasi mengajar. Jensen \& Nickelsen (2011: 60) mengatakan bahwa pembelajaran yang menyenangkan dapat menimbulkan motivasi intrinsik juga dapat meningkatkan skor tes standar yang lebih tinggi dan mengurangi kecemasan. Melalui pembelajaran yang menyenangkan siswa akan dapat menikmati pembelajaran yang berlangsung. Semakin senang siswa dengan pekerjaan rumah yang diberikan oleh guru maka kecemasan siswa pun semakin kecil.

Sardiman (2010: 85) mengemukakan beberapa fungsi motivasi yaitu: 1) Mendorong manusia untuk berbuat, yaitu sebagai penggerak atau motor yang melepaskan energy, 2) Menentukan arah perbuatan, yakni ke arah tujuan yang hendak dicapai dan 3) Menyeleksi perbuatan, yakni menentukan perbuatan-perbuatan apa yang harus dikerjakan yang serasi guna mencapai tujuan, dengan menyisihkan perbuatanperbuatan yang tidak bermanfaat bagi tujuan tersebut.
Berdasarkan uraian tersebut, jelas bahwa pentingnya motivasi belajar bagi siswa dalam pembelajaran, dimana dapat dijadikan sebagai salah satu pemecahan masalah belajar pada siswa. Dengan adanya motivasi yang tumbuh kuat dalam diri seseorang maka hal itu akan menjadi modal penggerak utama dalam mengerjakan sesuatu. Sebagaimana juga siswa dalam belajarnya tentunya ia membutuhkan motivasi guna mencapai keberhasilan.

Menurut Imron (Siregar \& Nara, 2011: 53-54) mengemukakan enam unsur atau faktor yang mempengaruhi motivasi pembelajaran. Keenam faktor tersebut ialah: 1) cita-cita atau aspirasi pembelajar, 2) kemampuan pembelajar, 3) kondisi pembelajar, 4) kondisi lingkungan pembelajar, 5) unsur-unsur dinamis belajar atau pembelajaran dan 6) upaya guru dalam membelajarkan pembelajaran. Dalam meningkatkan motivasi belajar siswa maka faktor dalam diri siswa dan faktor yang berasal dari luar atau dari lingkungan siswa. Kedua faktor tersebut saling terkait dan saling berpengaruh dalam upaya meningkatkan motivasi belajar siswa. Jika hanya salah satu faktor saja maka upaya meningkatkan motivasi belajar tidak akan maksimal.

Motivasi dapat menentukan baik tidaknya dalam mencapai tujuan sehingga semakin besar motivasi yang dimiliki oleh seseorang, semakin besar pula kesuksesan belajarnya. Seorang yang besar motivasinya, akan giat berusaha, tampak gigih dan tidak mau menyerah, giat membaca buku-buku untuk meningkatkan prestasi dan memecahkan masalahnya. Sebaliknya, mereka yang motivasinya rendah, tampak acuh tak acuh, mudah putus asa, perhatiannya tidak tertuju pada pelajaran, suka mengganggu kelas, sering meninggalkan pelajaran yang berakibat banyaknya kesulitan belajar. 
Seseorang yang memiliki motivasi belajar yang tinggi, tentunya dia akan berkreativitas secara aktif. Jika aktivitas terus terjadi dalam belajarnya, maka pengetahuan yang diperolehnya akan semakin banyak dan mendalam. Oleh karena itu hasil belajar yang diperolehnya pun diharapkan akan semakin baik. Hal tersebut sejalan dengan pendapat Rifa'i \& Anni (2009: 85) yang mengatakan bahwa hasil belajar merupakan perubahan perilaku yang diperoleh siswa setelah mengalami belajar. Perolehan aspek-aspek perubahan perilaku tersebut tergantung pada apa yang dipelajari oleh siswa. Apabila pendidik mempelajari pengetahuan tentang konsep maka perubahan perilaku yang diperoleh adalah berupa pengetahaun konsep.

Sudjana (2010: 22) menyatakan bahwa hasil belajar merupakan kemampuankemampuan yang dimiliki oleh siswa setelah ia menerima pengalaman belajarnya. Hasil belajar adalah perubahan perilaku secara keseluruhan bukan hanya satu aspek potensi kemanusian saja. Hal tersebut sejalan dengan Bloom (Rifa'I \& Anni, 2009: 86) mengatakan bahwa ada tiga taksonomi yang disebut dengan ranah belajar, yaitu ranah kognitif (cognitive domain), ranah afektif (afektive domain) dan ranah prikomotorik (psicomotoric domain).

Untuk mencapai hasil belajar yang baik dan memuaskan memang sangat banyak faktor yang mempengaruhinya, diantaranya adalah dari faktor guru dan diri siswa itu sendiri. Dalam hal ini guru berkewajiban menciptakan kegiatan belajar mengajar yang mampu menunjang dan mendorong siswa untuk mengembangkan segala potensi yang ada secara optimal, sehingga keberhasilan itu dapat diperoleh siswa.

Siswa yang menjadi subjek utama dalam penyelenggaraan pendidikan dan pembelajaran, tentunya perlu memperhatikan strategi pembelajaran sebagai segala usaha guru dalam menerapkan berbagai metode pembelajaran untuk mencapai tujuan yang diharapkan. Pemilihan strategi pembelajaran hendaknya mempertimbangkan tahap perkembangannya. Siswa yang berbeda usia akan berbeda pula cara pikir dan juga kekuatan mentalnya. Piaget (Isjoni, 2010: 36) membagi perkembangan kognitif manusia menjadi empat tahap yaitu: (1) Tahap sensorimotor (umur 0-2 tahun); (2) Tahap pra-operasional (umur 2-7 tahun); (3) Tahap operasional konkret (umur 7-12 tahun); (4) Tahap operasional formal (umur 12-18 tahun).

Dilihat dari tahap perkembangan kognitif yang diutarakan Piaget, siswa sekolah dasar termasuk dalam tahap operasional konkret. Dalam tahap operasional konkret anak-anak mampu berpikir operasional. Mereka dapat mempergunakan berbagai simbol, melakukan berbagai bentuk operasional, yaitu kemampuan aktivitas mental sebagai kebalikan dari aktivitas jasmani yang merupakan dasar untuk mulai berpikir dalam aktivitasnya. Menurut Sumantri \& Syaodih (2007: 63-64) karakteristik anak usia sekolah dasar yaitu; (1) senang bermain; (2) senang bergerak; (3) senang bekerja dalam kelompok; (4) senang merasakan atau melakukan sesuatu secara langsung.

Dengan memahami karakteristik peserta didik, guru dapat menggunakan metode pembelajaran yang tepat. Dalam penelitian ini memfokuskan pada karakteristik anak usia sekolah dasar yang suka bermain, senang melakukan secara langsung, sehingga guru menggunakan metode role playing mengedepankan interaksi antar siswa, sehingga siswa turut aktif dalam pembelajaran dengan mengkonstruksi pengetahuan bersama teman-temannya dan diharapkan proses pembelajaran dapat berlangsung dengan efektif dan efisien, serta optimal. 
Menurut Achmad (Hidayati, 2004: 93) role playing adalah salah satu bentuk permainan pendidikan yang dipakai untuk menjelaskan peranan, sikap, tingkah laku, dan nilai dengan tujuan menghayati perasaan, sudut pandang dan cara berpikir orang lain. Metode role playing ditekankan kepada setiap individu siswa dalam memerankan suatu tokoh pada drama yang bersangkutan. Dengan metode role playing siswa diharapkan dapat memerankan berbagai figure dan menghayati dalam berbagai situasi. Jika metode role playing direncanakan dengan baik dapat menanamkan kemampuan bertanggung jawab dan bekerja sama dengan orang lain, menghargai pendapat orang lain dan mengambil keputusan dalam kerja kelompok.

Menurut Sugihartono (2006: 83) metode role playing adalah metode pembelajaran melalui pengembangan imajinasi dan penghayatan siswa dengan cara siswa memerankan suatu tokoh baik tokoh hidup maupun tokoh mati, sehingga siswa berlatih untuk penghayatan dan terampil memakai materi yang dipelajari. Berdasarkan uraian tersebut dapat disimpulkan bahwa metode role playing adalah cara bermain peran yang ditekankan pada setiap individu dengan berbagai figure penghayatan dan perasaan. Huda (2013: 115) menjelaskan bahwa esensi role playing adalah keterlibatan partisipan dan peneliti dalam situasi permasalahan dan adanya keinginan untuk memunculkan resolusi damai serta memahami apa yang dihasilkan dari keterlibatan langsung ini. Dengan cara belajar mengajar semacam ini para siswa diberi kesempatan, mengungkapkan, mengekspresikan suatu sikap tingkah laku yang diperlukan, dirasakan atau diinginkan sesuai dengan perannya.

Metode role playing dapat diterapkan pada pembelajaran PKn dengan pokok bahasan Musyawarah. Melalui metode role playing ini dapat melibatkan tiga aspek yaitu aspek kognitif, afektif, dan psikomotor. Aspek kognitif meliputi pemecahan masalah, aspek afektif meliputi saling menghargai tolenransi dan bersikap lapang dada, aspek psikomotor saat siswa melakukan role playing

\section{METODE PENELITIAN}

Penelitian ini menggunakan pendekatan kualitatif. Laporan penelitian menggunakan análisis deskriptif yang merupakan pendekatan dengan mempertahankan keutuhan (wholeness) obyek. Adapun jenis penelitian yang diterapkan pada penelitian ini adalah Penelitian Tindakan Kelas (PTK). Menurut Arikunto, dkk (2007: 58) Penelitian Tindakan Kelas atau PTK adalah suatu penelitian praktis yang bertujuan untuk memperbaiki kekurangan-kekurangan yang ada dalam pembelajaran di kelas, dengan cara melakukan tindakan-tindakan tertentu agar dapat memperbaiki atau meningkatkan pembelajaran di kelas. Penelitian ini difokuskan pada proses pembelajaran PKn dengan menerapkan metode role playing yaitu Guru dan Siswa dan Hasil belajar siswa pada pembelajaran PKn.

Setting dalam penelitian tindakan kelas ini adalah setting di dalam ruang kelas II, yaitu pada waktu kegiatan belajar mengajar PKn berlangsung di SDN 1 Enrekang. Subyek yang dibutuhkan penelitian ini adalalah seluruh siswa kelas II SDN 1 Enrekang yang berjumlah 18 siswa yang terdiri dari 6 siswa laki-laki dan 12 siswa perempuan dan guru kelas dua yang mengampu mata pelajaran PKn. Penelitian tindakan kelas (Class Room Action Research) ini terdiri atas tiga siklus. Setiap siklus dilakukan empat rangkaian kegiatan. Empat kegiatan utama yang ada pada setiap siklus menurut Arikunto dkk, (2006: 18-19) yaitu :(1). Perencanaan (Planning), (2). Tindakan (Acting), (3). Pengamatan 
(Observing), (4). Refleksi (Reflecting), yang

dapat digambarkan sebagai berikut:

Gambar 1. Bagan Pelaksanaan Tindakan Penelitian

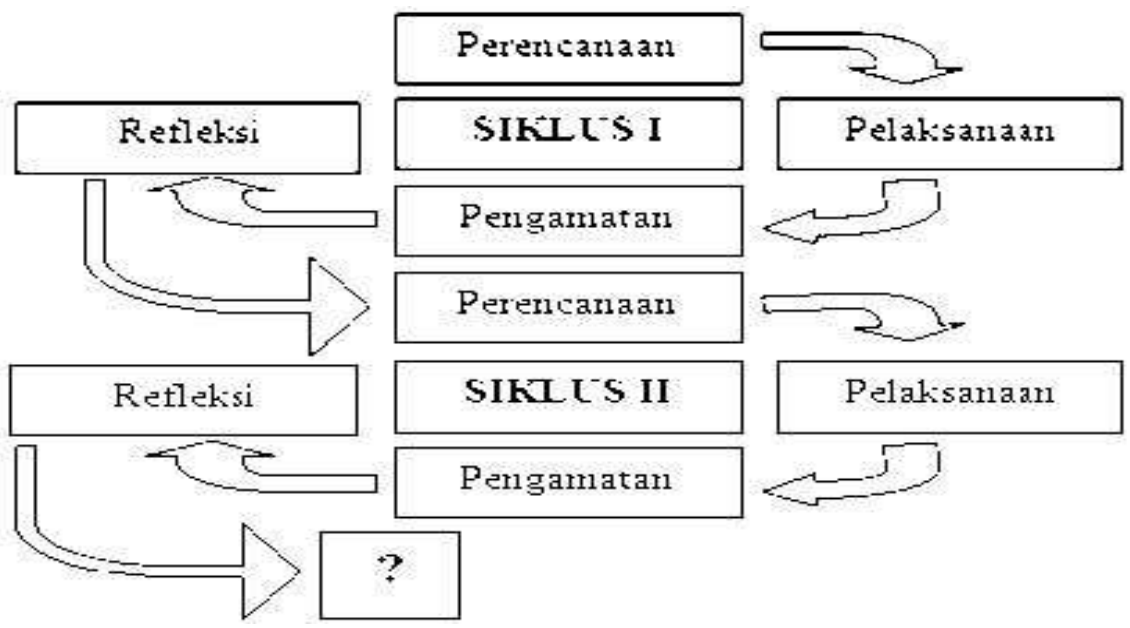

Sumber: Diadaptasi dari Suharsimi Arikunto (2006: 16)

Pengumpulan data yang dilakukan dalam penelitian ini melalui teknik pengumpulan data yaitu 1) Angket atau Kuesioner, Observasi dan Dokumentasi. Analisis data dalam penelitian tindakan kelas ini menggunakan teknik analisis deskriptif kualitatif dimana data kualitatif berupa data angket dan hasil observasi motivasi belajar siswa dan aktivitas guru dalam pembelajaran $\mathrm{PKn}$ melalui metode role playing. Analisis data kualitatif yang digunakan dalam penelitian ini mengacu pada model Miles dan Hubermen (Sudjono, 2005: 321-322) yang meliputi tiga langkah yaitu: 1) Data reduction (reduksi data) berarti merangkum, merumuskan hal-hal pokok, memfokuskan pada hal-hal penting, dicari pola temanya dan membuang hal yang tidak perlu, 2) Data display (penyajian data) menyajikan data dengan teks yang bersifat naratif dan 3) Conclusing drawing/ Verivication adalah pengambilan kesimpulan atau intisari dalam bentuk kalimat.

\section{HASIL DAN PEMBAHASAN}

Untuk mengetahui data awal tentang motivasi, peneliti memberikan angket kepada siswa untuk mengetahui motivasi belajar awal siswa dalam pelajaran PKn. Hasil analisis data angket motivasi belajar siswa kelas II SDN 1 Enrekang diperoleh bahwa dari 30 siswa kelas II SDN 1 Enrekang yang mengisi angket, ada 14 siswa atau $46,67 \%$ telah mencapai indicator motivasi belajar dan ada 16 siswa atau 53,33 $\%$. Hasil analisis data awal ketercapain motivasi belajar PKn siswa diperoleh presentase sebesar $46,67 \%$. Hal ini berarti bahwa belum mencapai batas capaian indikator motivasi belajar PKn siswa yang telah ditetapkan yaitu $70 \%$. Dari data tersebut jelas bahwa masih kurangnya motivasi belajar siswa dalam mengikuti pembelajaran PKn.

Data awal hasil belajar PKn siswa diperoleh rata-rata kelas adalah 68,3. Dimana terdapat 5 siswa atau $16,67 \%$ dengan kategori baik sekali, 12 siswa atau $40 \%$ dengan kategori baik, 10 siswa atau 
33,33\% dengan kategori cukup dan 3 siswa atau $10 \%$. Maka diperoleh prosentase ketuntasan belajar siswa sebesar $56,67 \%$, hal ini berarti bahwa belum mencapai batas KKM (Kriteria Ketuntasan Minimal) yang telah ditetapkan yaitu $70 \%$. Keadaan ini menunjukkan bahwa hasil belajar PKn siswa belum tuntas.

Berdasarkan hasil analisis penelti dari kedua data awal tersebut, menunjukkan bahwa terdapat hubungan antara motivasi dengan hasil belajar siswa. Motivasi belajar siswa yang rendah akan mempengaruhi hasil belajar siswa. Hal inilah yang mendasari peneliti untuk melaksanakan pembelajaran dengan metode role playing guna mengatasi masalah tersebut. Proses pembelajaran yang dilakukan secara langsung akan membantu siswa memahami materi ajar dan dapat mencari solusi atas permasalahan belajar yang dihadapinya.

\section{SIKLUS I}

Siklus I dilaksanakan dalam 2 kali pertemuan dengan alokasi waktu 2 x 35 menit dengan materi yang diajarkan adalah Musyawarah. Hasil analisis data hasil belajar PKn siswa pada siklus I diperoleh rata-rata kelas adalah 70,17. Dimana terdapat 6 siswa atau 20\% dengan kategori baik sekali, 14 siswa atau 46, 67\% dengan kategori baik, 7 siswa atau 23,33\% dengan kategori cukup dan 3 siswa atau 10\%. Hasil analisis presentase ketuntasan belajar siswa pada siklus I sebesar 66,67\%, hal ini berarti bahwa belum mencapai batas KKM (Kriteria Ketuntasan Minimal) yang telah ditetapkan yaitu 70\%. Keadaan ini menunjukkan bahwa hasil belajar PKn siswa belum tuntas.

Data motivasi belajar PKn siswa pada siklus I berupa angket motivasi belajar PKn siswa. Hasil analisis data angket motivasi belajar PKn siswa pada siklus I diperoleh 4 siswa atau $13,33 \%$ dengan kategori sangat tinggi, 16 siswa atau 53,33\% dengan kategori tinggi, 10 siswa atau 33,33 $\%$ dengan kategori sedang. Berdasarkan hasil analisis ketercapaian motivasi belajar PKn siswa pada siklus I berupa angket diperoleh presentase sebesar 66,67\%. Hal ini berarti bahwa belum mencapai batas capaian indikator motivasi belajar PKn siswa yang telah ditetapkan yaitu $70 \%$.

Hasil observasi motivasi belajar PKn siswa pada pertemuan $\mathrm{k}-1$ diperoleh 5 siswa atau $16,67 \%$ dengan kategori sangat tinggi dari kelompok yang diharapkan, 13 siswa atau $43,33 \%$ dengan kategori tinggi dari kelompok yang diharapkan, 12 siswa atau $40 \%$ dengan kategori sedang dari kelompok yang tidak diharapkan. Sedangkan hasil observasi pada pertemuan ke-2 diperoleh 7 siswa atau 23,33\% dengan kategori sangat tinggi dari kelompok yang diharapkan, 15 siswa atau 50\% dengan kategori tinggi dari kelompok yang diharapkan, 8 siswa atau $26,67 \%$ dengan kategori sedang dari kelompok yang tidak diharapkan. Berdasarkan data tersebut terlihat bahwa terdapat peningkatan motivasi belajar PKn siswa pada kategori yang diharapkan.

Berdasarkan hasil analisis ketercapaian motivasi belajar PKn siswa pada siklus I berupa lembar observasi diperoleh presentase sebesar $60 \%$ pada pertemuan ke-1 sedangkan pada pertemuan ke-2 diperoleh prosentase sebesar 73,33\%. Hal ini berarti bahwa terjadi peningkatan motivasi belajar PKn siswa, dimana pertemuan ke-2 pada siklus I mencapai batas capaian indikator motivasi belajar PKn siswa yang telah ditetapkan yaitu $70 \%$. Walaupun terjadi peningkatan pada motivasi belajar PKn siswa, peneliti masih tetap melanjutkan penelitian pada siklus berikutnya.

Hasil analisis keterlaksanaan pembelajaran guru dengan menerapkan metode role playing pada pertemuan ke-1 diperoleh sebesar $63,16 \%$ dengan kategori cukup sedangkan pada pertemuan ke-2 
diperoleh sebesar 73,68\% dengan kategori cukup. Hal ini berarti bahwa terjadi peningkatan pada keterampilan guru dalam melaksanakan pembelajaran dengan menerapkan metode role playing. Walaupun terjadi peningkatan pada keterampilan guru dalam melaksanakan pembelajaran dengan menerapkan metode role playing, namun guru/peneliti tetap melanjutkan tindakan agar mengurangi kekurangan yang terjadi pada siklus I dan peneliti harus lebih baik dalam melaksanakan pembelajaran dengan metode role playing untuk meningkatkan motivasi dan hasil belajar siswa pada mata pelajaran PKn.

Setelah melalui tahap perencanaan, pelaksanaan dan observasi, peneliti melakukan tahap refleksi dari kegiatan siklus I. Data-data hasil penelitian terhadap proses pembelajaran yang dilaksanakan oleh guru/peneliti dan siswa kemudian direfleksi oleh peneliti. Berdasarkan hasil pengamatan terhadap masalah-masalah selama pelaksanaan proses pembelajaran pada siklus I, hasil observasi dan angket motivasi belajar PKn dan hasil tes akhir dapat di simpulan bahwa: 1) Siswa masih belum terbiasa menggunakan metode role playing. Ini terlihat saat bermain peran siswa masih terlihat bingung, 2) Siswa masih kurang aktif menyampaikan pendapat, masih banyak siswa yang pasif saat pembelajaran. Hanya beberapa yang terlihat aktif saat belajar, 3) Hasil motivasi belajar berdasarkan hasil observasi dan angket motivasi belajar yang dilakukan pada siklus I, menunjukkan bahwa masih belum memenuhi ketercapaian indicator motivasi belajar, 4) Pada saat mengerjakan soal evaluasi masih ada siswa yang kurang percaya diri dengan kemampuannya, terlihat masih ada yang mencontek pekerjaan temannya dan 5) Hasil belajar siswa berdasarkan hasil tes yang dilakukan pada siklus I, menunjukkan bahwa belum memenuhi ketuntasan hasil belajar. Ditinjau dari beberapa masalah yang terjadi maka perlu dilakukan beberapa tindakan untuk mengatasinya, antara lain: 1) Menjelaskan tentang metode role playing dan manfaat ketika belajar dengan metode role playing; 2) Mengaktifkan dan mendorong siswa untuk mengemukakan pendapat, terutama pada siswa yang pasif dalam proses pembelajaran; 3) Meningkatkan rasa percaya diri dan memberi keyakinan kepada siswa bahwa dia mampu untuk menyelesaikan pekerjaannya sendiri dengan baik dan benar; dan 4) Peneliti memperhatikan dan memberikan pembinaan lebih pada siswa agar hasil belajar siswa dapat meningkat.

Berdasarkan hasil refleksi pada siklus I dapat disimpulkan bahwa, secara umum pada siklus I sudah menunjukkan adanya peningkatan motivasi dan hasil belajar PKn siswa serta keberhasilan peneliti dalam menerapkan metode role playing. Namun penelitian perlu melanjutkan pada siklus II agar motivasi dan hasil belajar PKn siswa bisa meningkat sesuai yang diharapkan. Selanjutnya peneliti berkonsultasi pada pembimbing untuk melanjutkan ke siklus II.

\section{SIKLUS II}

Pembelajaran pada siklus II ini merupakan perbaikan dari pembelajaran pada siklus I. Hasil tes yang diperoleh untuk mengetahui pemahaman siswa tentang materi yang telah diajarkan pada siklus II rata-rata kelas adalah 79. Dimana terdapat 12 siswa atau $40 \%$ dengan kategori baik sekali, 14 siswa atau $50 \%$ dengan kategori baik, 3 siswa atau $10 \%$ dengan kategori cukup. Hasil perolehan nilai tes hasil belajar PKn siswa mengalami peningkatan dibandingan dengan nilai pada siklus I. Hasil analisis presentase ketuntasan belajar siswa pada siklus II sebesar $90 \%$, hal ini berarti bahwa telah mencapai batas KKM (Kriteria Ketuntasan Minimal) yang telah ditetapkan yaitu $70 \%$ Keadaan ini 
menunjukkan bahwa hasil belajar PKn siswa telah meningkat.

Data motivasi belajar PKn siswa pada siklus II berupa angket motivasi belajar PKn siswa diperoleh 15 siswa atau 50\% dengan kategori sangat tinggi, 13 siswa atau 43,33\% dengan kategori tinggi, 2 siswa atau $6,67 \%$ dengan kategori sedang. Hasil angket motivasi belajar PKn siswa pada siklus II mengalami peningkatan dibandinkan dengan pada siklus I. Berdasarkan hasil analisis ketercapaian motivasi belajar PKn siswa pada siklus I berupa angket diperoleh presentase sebesar 93,33\%. Hal ini berarti bahwa telah mencapai batas capaian indikator motivasi belajar PKn siswa yang telah ditetapkan yaitu $70 \%$.

Hasil observasi motivasi belajar PKn siswa pada pertemuan k-1 diperoleh 9 siswa atau 30\% dengan kategori sangat tinggi dari kelompok yang diharapkan, 17 siswa atau $56,67 \%$ dengan kategori tinggi dari kelompok yang diharapkan, 4 siswa atau $13,33 \%$ dengan kategori sedang dari kelompok yang tidak diharapkan. Sedangkan hasil observasi pada pertemuan ke-2 diperoleh 15 siswa atau 50\% dengan kategori sangat tinggi dari kelompok yang diharapkan, 13 siswa atau 43,33\% dengan kategori tinggi dari kelompok yang diharapkan, 2 siswa atau 6,67\% dengan kategori sedang dari kelompok yang tidak diharapkan. Berdasarkan data tersebut terlihat bahwa terdapat peningkatan motivasi belajar PKn siswa pada kategori yang diharapkan.

Hasil analisis ketercapaian motivasi belajar PKn siswa pada siklus II berupa lembar observasi diperoleh presentase sebesar $86,67 \%$ pada pertemuan ke-1 sedangkan pada pertemuan ke-2 diperoleh prosentase sebesar 93,33\%. Hal ini berarti bahwa terjadi peningkatan motivasi belajar PKn siswa, dimana pertemuan ke-2 pada siklus I mencapai batas capaian indikator motivasi belajar PKn siswa yang telah ditetapkan yaitu $70 \%$.

Hasil observasi keterlaksanaan pembelajaran guru dengan menerapkan metode role playing siklus II pada pertemuan ke-1 diperoleh sebesar 84,21\% dengan kategori baik sedangkan pada pertemuan ke-2 diperoleh sebesar $89,47 \%$ dengan kategori sangat baik. Hal ini berarti bahwa terjadi peningkatan kualitas proses pembelajaran dengan menerapkan metode role playing.

Setelah melewati tahap perencanaan, pelaksanaan, observasi, dan wawancara peneliti melakukan kegiatan refleksi dari kegiatan siklus II. Berdasarkan hasil pengamatan terhadap masalah-masalah selama pelaksanaan proses pembelajaran pada siklus II, hasil observasi, hasil catatan lapangan, dan hasil tes akhir diperoleh kesimpulan yaitu: 1) Kepercayaan diri siswa terhadap kemampuannya sendiri sudah meningkat terbukti dengan tidak ada lagi siswa yang contekan pekerjaan temannya dalam mengerjakan soal-soal evaluasi, 2) Hasil belajar siswa berdasarkan hasil test siklus II menunjukkan bahwa hasil belajar siswa terhadap materi sikap dalam musyawarah, telah memenuhi KKM yang di tetapkan. Oleh karena itu tidak perlu adanya pengulangan siklus, 3) Melihat dari hasil observasi kegiatan guru dan siswa, sudah banyak terjadi peningkatan dan tergolong baik, terlihat siswa lebih aktif, berani berinteraksi, berani mengungkapkan pendapat dan bertanya, dan senang dalam pembelajaran dengan metode role playing serta meningkatnya motivasi belajar PKn siswa. Berdasarkan hasil refleksi pada siklus II dapat disimpulkan bahwa, secara umum pada siklus II sudah menunjukkan adanya peningkatan motivasi belajar dan hasil belajar PKn siswa serta keberhasilan peneliti dalam menggunakan metode role playing. Oleh karena itu tidak diperlukannya pengulangan siklus. 


\section{PEMBAHASAN HASIL PENELITIAN}

Hasil belajar PKn pada kondisi awal atau sebelum tindakan masih rendah. Hal ini ditunjukkan dengan dokumen guru berupa nilai hasil belajar PKn siswa yang secara umum masih rendah. Hal lain yang mendukung yaitu aktifnya siswa dalam mengikuti pelajaran, proses pembelajaran masih didominasi oleh guru, sehingga siswa terlihat pasif dalam proses pembelajaran sesuai pengamatan dan pengalaman selama ini. Kurangnya aktivitas siswa dalam proses pembelajaran menjadikan perhatian dan motivasi siswa kurang terhadap materi yang dipelajari, sehingga tingkat pemahaman siswa terhadap materi yang dipelajari juga rendah. Rendahnya tingkat pemahaman siswa terhadap materi yang dipelajari berdampak terhadap hasil belajar yang diperoleh siswa. Berdasarkan dokumen guru berupa nilai hasil belajar PKn sebelum pelaksanaan tindakan, diketahui bahwa hasil belajar PKn siswa belum tuntas yaitu $56,67 \%$, hal ini berarti bahwa belum mencapai batas KKM (Kriteria Ketuntasan Minimal) yang telah ditetapkan yaitu $70 \%$.

Berdasarkan kondisi pada saat tersebut, peneliti berkeinginan melakukan penelitian tindakan kelas dengan menerapkan metode pembelajaran role playing pada mata pelajaran PKn. Pemilihan metode pembelajaran role playing disebabkan karena keunggulan yang dimilikinya. Metode pembelajaran role playing merupakan suatu cara penguasaan bahan-bahan pelajaran melalui pengembangan imajinasi dan penghayatan siswa (Hamdani, 2011: 87). Pada metode ini, pengembangan imajinasi dan penghayatan dilakukan siswa dengan memerankannya sebagai tokoh hidup dan benda mati. Pengembangan imajinasi dan penghayatan menjadikan siswa dapat lebih memahami materi atau konsep yang dipelajari.

Penggunaan metode pembelajaran role playing pada mata pelajaran PKn tepat karena ciri khas pembelajaran PKn adalah menekankan pada aspek pendidikan, yaitu siswa diharapkan memperoleh pemahaman konsep dan mengembangkan serta melatih sikap, nilai, moral, dan keterampilannya berdasarkan konsep yang telah dimilikinya (Solihatin, 2008: 14). Penggunaan metode role playing disebabkan karena keuntungan menggunakan metode itu sendiri, yaitu siswa lebih tertarik perhatianya pada pelajarannya; melalui bermain peran sendiri, mereka mudah memahami masalah-masalah sosial tersebut; melalui bermain peran sebagai orang lain, siswa dapat menempatkan diri seperti watak orang lain, dan siswa dapat merasakan perasaan orang lain sehingga menumbuhkan sikap saling perhatian.

Berdasarkan hasil tes evaluasi hasil belajar PKn yang dikerjakan oleh siswa, terlihat adanya peningkatan hasil belajar PKn siswa data awal sebelum tindakan, Siklus I, dan Siklus II. Nilai rata-rata pada kondisi awal/pra tindakan hanya sebesar 68,33, meningkat pada Siklus I menjadi 70,17 , dan meningkat lagi pada siklus II menjadi 79. Peningkatan nilai rata-rata menunjukkan bahwa nilai hasil belajar PKn siswa mengalami peningkatan. Untuk lebih jelasnya dapat dilihat pada tabel berikut: 


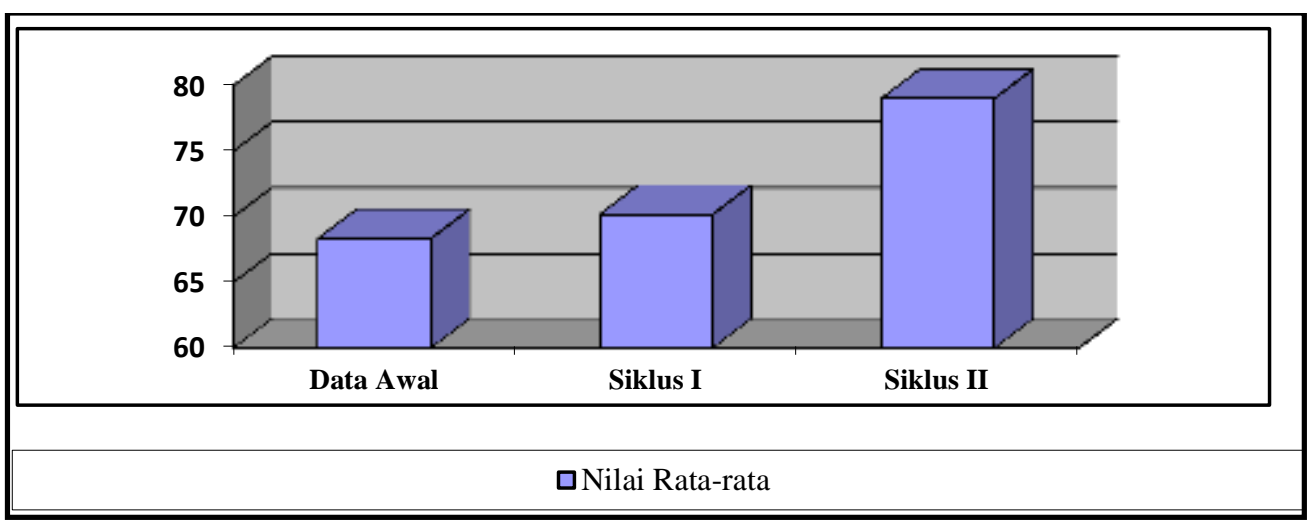

Gambar 2. Grafik Nilai Rata-rata Hasil Belajar PKn Siswa

Selain itu, peningkatan nilai hasilbelajar PKn siswa juga berdampak positif pada peningkatan jumlah siswa yang tuntas belajar. Peningkatan ketuntasan belajar secara klasikal dapat dilihat dari adanya peningkatan persentase jumlah siswa yang sudah tuntas. Presentase ketuntasan belajar pada kondisi awal/pra tindakan hanya sebesar 56,67\%, meningkat pada Siklus I menjadi $66,67 \%$, dan meningkat lagi pada siklus II menjadi $90 \%$. Prosentase ketuntasan belajar menunjukkan bahwa Prosentase ketuntasan belajar PKn siswa mengalami peningkatan. Untuk lebih jelasnya dapat dilihat pada tabel berikut:

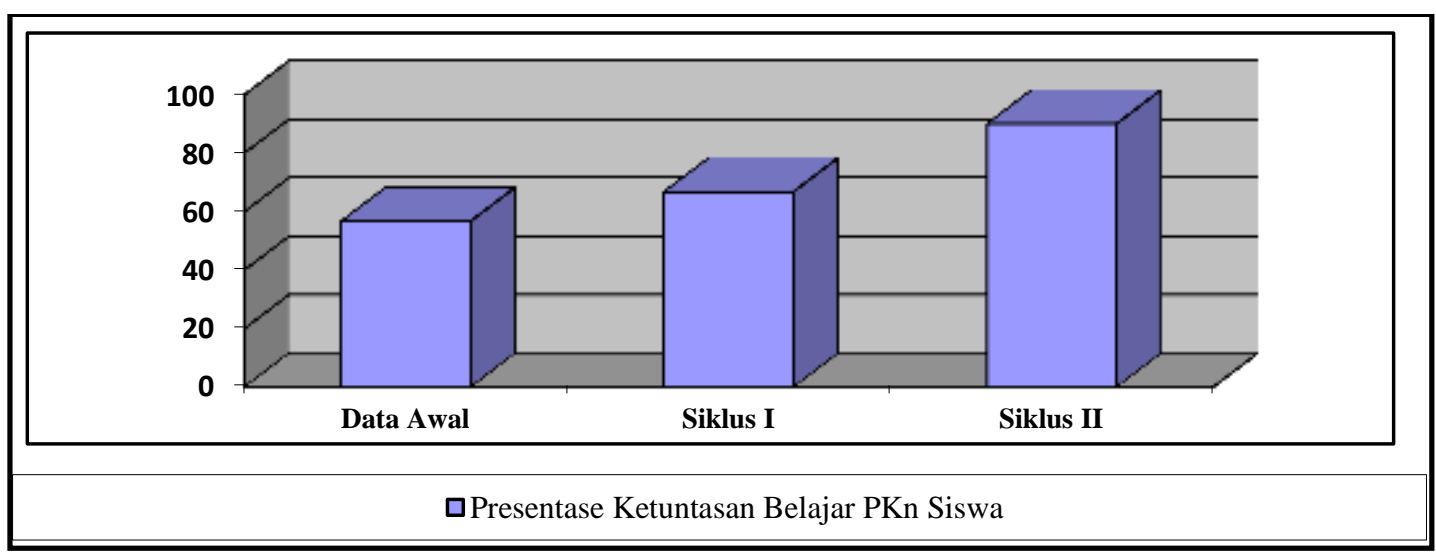

Gambar 3. Grafik Prosentase Ketuntasan Belajar PKn Siswa

Berdasarkan hasil observasi motivasi belajar PKn yang peroleh, terlihat adanya peningkatan motivasi hasil belajar PKn siswa pada siklus I sebesar $60 \%$ pada pertemuan ke-1 dan pertemuan ke-2 diperoleh presentase sebesar 73,33\% sedangkan pada siklus II diperoleh presentase sebesar $86,67 \%$ pada pertemuan ke-1 sedangkan dan pertemuan ke-2 diperoleh presentase sebesar 93,33\%. Peningkatan skor presentase siswa menunjukkan bahwa motivasi belajar PKn siswa mengalami peningkatan. Untuk lebih jelasnya dapat dilihat pada tabel berikut: 


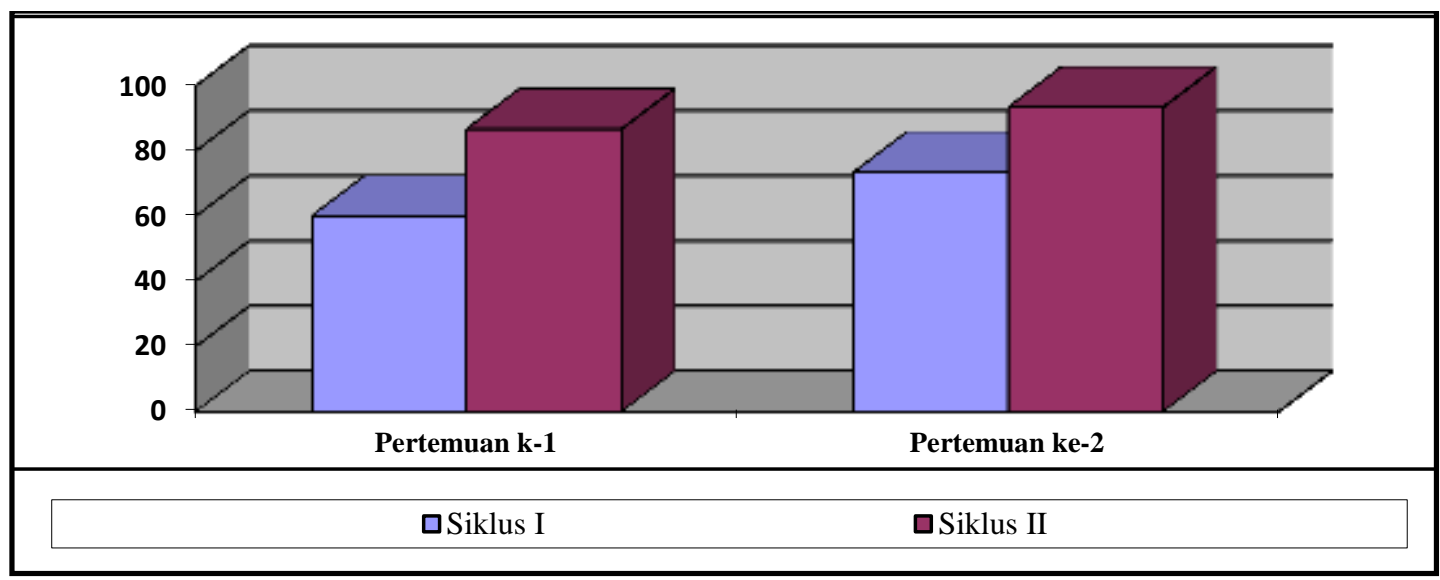

Gambar 4. Grafik Presentase Observasi Motivasi Belajar PKn Siswa

Berdasarkan hasil angket motivasi belajar PKn yang diisi oleh siswa, terlihat adanya peningkatan motivasi belajar PKn siswa dari data awal sebelum tindakan, Siklus I, dan Siklus II. Skor prosentase yang diperoleh pada kondisi awal/pra tindakan hanya sebesar 46,67\%, meningkat pada
Siklus I menjadi 66,67\% dan meningkat lagi pada siklus II menjadi 93,33\%. Peningkatan skor presentase menunjukkan bahwa motivasi belajar PKn siswa mengalami peningkatan. Untuk lebih jelasnya dapat dilihat pada tabel berikut:

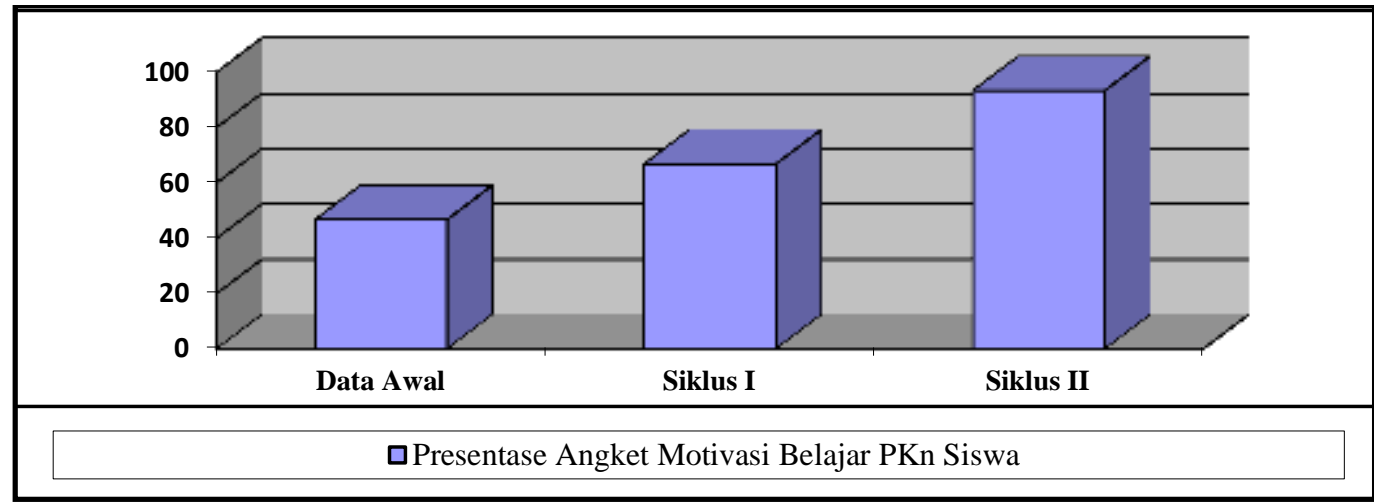

Gambar 5. Grafik Presentase Angket Motivasi Belajar PKn Siswa

Berdasarkan hasil observasi dan angket motivasi belajar $\mathrm{PKn}$ siswa mengalami peningkatan karena siswa merasa tertarik dalam menerapkan pembelajaran dengan metode role playing dimana metode pembelajaran ini merupakan permainan yang menyenangkan bagi siswa. Hal ini senada yang dikemukakan Hamdani (2011: 87) yang menyatakan bahwa metode role playing merupakan metode yang diterapkan melalui permainan dan permainan merupakan pengalaman yang menyenangkan bagi siswa. motivasi belajar PKn mengalami peningkatan karena metode role playing merupakan salah satu metode yang dapat meningkatkan pemahaman siswa terhadap materi pelajaran.

Adanya peningkatan tersebut menunjukkan bahwa motivasi belajar siswa bertambah sehingga berdampak pada hasil belajar siswa yang mengalami peningkatan. Peningkatan tersebut sudah mencapai 
indikator ketercapaian yang ditentukan. Nilai siswa secara individu mengalami peningkatan yang baik. Hal ini menjadikan nilai rata-rata kelas dan persentase ketuntasan secara klasikal juga meningkat. Dengan adanya peningkatan tersebut, maka terbukti bahwa penerapan metode pembelajaran role playing mampu meningkatkan motivasi dan hasil belajar PKn siswa.

Hasil penelitian ini mendukung hasil penelitian yang dilakukan oleh Ratna Puspita Dewi dan Ganes Gunansyah (2014) yang menunjukkan bahwa peningkatan motivasi dan hasil belajar siswa kelas $\mathrm{V}$ SDN Kedunggempol, Mojokerto. Peningkatan motivasi dan hasil belajar dibuktikan dengan skor motivasi belajar dan hasil belajar siswa memperoleh nilai tuntas. Selain itu penelitian ini juga mendukung yang dilakukan oleh Ritha tuken (2016) yang menunjukkan bahwa peningkatan hasil belajar siswa pada mata pelajaran PKn kelas VI SDN IV Kota Parepare. Peningkatan hasil belajar dibuktikan dengan diperolehnya siklus I sebesar $66,67 \%$ dengan kualifikasi cukup dan siklus II sebesar $77 \%$ dengan kualifikasi baik. Adanya peningkatan nilai rata-rata dan jumlah siswa yang memperoleh nilai pada kategori tuntas membuktikan bahwa penerapan metode pembelajaran role playing dapat meningkatkan motivasi dan hasil belajar PKn siswa kelas II di SDN 1 Enrekang.

\section{SIMPULAN DAN SARAN}

Kegiatan perbaikan pembelajaran sebanyak dua siklus mata pelajaran PKn kelas II materi musyawarah melalui metode Role Playing di SDN 1 Enrekang semester II tahun pelajaran 2015/2016 berhasil dilaksanakan dengan baik dan hasilnya sangat memuaskan. Peningkatan hasil belajar siswa dan peningkatan motivasi siswa mengikuti pembelajaran pada setiap siklusnya benar-benar membuat peneliti dan guru belajar banyak. Demi meningkatnya hasil belajar, guru meluangkan banyak waktu untuk bersabar memilih, mempelajari meode dan alat peraga yang tepat sesuai dengan materi yang diajarkan. Dan setelah penulis melaksanakan perbaikan pembelajaran PKn dengan materi musyawarah melalui metode Role Playing ini. Penelit dapat mengambil kesimpulan yaitu: 1) Penerapan metode role playing pada mata pelajaran PKn materi musyawarah di SDN 1 Enrekang menumbuhkan motivasi belajar siswa sehingga hasil belajar siswa mengalami peningkatan, 2) Hasil belajar berupa nilai rata-rata kelas pada kondisi awal/pratindakan hanya sebesar 68,33, meningkat pada Siklus I menjadi 70,17, dan meningkat lagi pada siklus II menjadi 79 . Persentase ketuntasan belajar pada kondisi awal/pratindakan 56,67\%, meningkat pada Siklus I menjadi $66,67 \%$, dan meningkat lagi pada siklus II menjadi $90 \%$ dan 3) Metode pembelajaran role playing juga dapat diterapkan pada materi pokok yang lain.

Berdasarkan penelitian yang telah dilakukan, peneliti mempunyai beberapa saran yang disampaikan yaitu, kepada: 1) Bagi siswa disarankan agar hasil belajar yang baik yang telah diperoleh sebaiknya dipertahankan, 2) Guru harus membantu menciptakan suasana belajar yang menyenangkan, selain itu perlu disediakan alat peraga yang sesuai dengan materi yang diajarkan. Dalam pembelajaran yang menggunakan metode Role Playing, guru wajib memilih materi yang sesuai, karena tidak semua materi bisa di pelajari dengan menggunakan metode tersebut, 3) Mengingat model pembelajaran dengan metode Role Playing dapat mendorong siswa lebih aktif dan dapat meningkatkan motivasi dan hasil belajar siswa, diharapkan 
setiap sekolah dapat menerapkan metode pembelajaran tersebut.

\section{DAFTAR PUSTAKA}

[1] Agus Suprijono. 2012. Cooperatif Learning Teori Dan Aplikasi Palkem. Yogyakarta: Pustaka Belajar.

[2] Anni, C.T. \& A. Rifa'i. 2009. Psikologi Pendidikan. Semarang: Unnes Press.

[3] Cogan, J.J: Howaya, Rk. K. 1999. The Foundation of education. New York: Prentice hall, Inc.

[4] Depdikbud. 2006. Kurikulum Tingkat Satuan Pendidikan. Jakarta: Departemen Pendidikan dan Kebudayaan

[5] Depdiknas. 2006. Kurikulum Tingkat satuan pendidikan mata pelajaran PKn. Jakarta: Departemen Pendidikan Nasional

[6] Dimyati \& Mudjiono. 2002. Belajar Dan Pembelajaran. Jakarta: Rineka Cipta.

[7] Dimyati dan Mudjiono. 2009. Belajar dan Pembelajaran. Jakarta: Rineka Cipta.

[8] Hamdani. 2011. Strategi Belajar Mengajar. Bandung: CV Pustaka Setia.

[9] Jensen, Eric, LeAnn Nickelsen. 2011. Deeper Learning: Strategi Luar Biasa Yang Tidak Mendalam dan Tak Terlupakan, Jakarta: Indeks.
[10] Miftahul Huda. 2013. Model-model Pengajaran dan Pembelajaran. Yogyakarta: Pustaka Pelajar.

[11] Moedjiono dan Moh. Dimyati. 1991. Strategi Belajar Mengajar. Jakarta: Departemen Pendidikan dan Kebudayaan Direktorat Jenderal Pendidikan Tinggi Proyek Pembinaan Tenaga Kependidikan.

[12] Nana sudjana. 2009. Penilaian Hasil Proses Belajar Mengajar. Bandung: PT Remaja Rosdakarya

[13] Nuruddin, Parman, Eko. 2009. Pendidikan Kewarganegaraan 2.: Untuk SD/MI kelas II Jakarta: Pusat Perbukuan, Departemen Pendidikan Nasional, 2009

[14] Sardiman A.M. 2007. Interaksi dan Motivasi dalam Belajar Mengajar. Jakarta: PT. Grafindo Persada

[15] Sardiman. 2010. Interaksi \& Motivasi Belajar Mengajar. Jakarta: PT RajaGrafindo Persada.

[16] Schunk, Dale H, Paul R. Pintrich, Judith L. Meece. 2010. Motivation in Education, Theory, Reasearch, and Applications. Ohio, New Jersey.

[17] Sugihartono, dkk. 2006. Psikologi Pendidikan. Yogyakarta: UNY.

[18] Suharsimi Arikunto, Suhardjono, dan Supardi. 2006. Penelitian Tindakan Kelas. Jakarta: PT. Bumi Aksara.

[19] Woolfolk, Anita. 2004. Educational Psychology: ninth edition. United States of America: Pearson Education. 